\title{
BIOMONITORING KUALITAS AIR SUNGAI MADIUN DENGAN BIOINDIKATOR MAKROINVERTEBRATA
}

\author{
Joko Widiyanto, Ani Sulistayarsi \\ Progrm Studi Pendidikan Biologi IKIP PGRI Madiun \\ joko_widiyanto@ymail.com
}

\begin{abstract}
ABSTRAK
Tujuan yang ingin dicapai dalam penelitian ini adalah untuk mengetahui keanekaragaman spesies makroinvertebrata dan kualitas Sungai Madiun dengan menggunakan makroinvertebrata sebagai bioindikator, sehingga hasil penelitian ini dapat digunakan sebagai dasar acuan penggunaan air Sungai Madiun dalam peruntukan kebutuhan masyarakat.

Metode yang digunakan dalam penelitian ini adalah biomonitoring dengan bioindikator makroinvertebrata, teknik yang digunakan dalam mengambil sampel adalah dengan teknik purposive random sampling, sampling dilakukan di empat stasiun yaitu bagian hulu bagian tengah dan bagian hilir, pengambilan sampel dilakukan setiap 2 minggu sekali selama dua bulan. Analisis data yang digunakan adalah dengan menggunakan Famili Biotik Indeks (FBI) yang didukung oleh paramater fisik dan kimia.

Dari penelitian yang telah dilakkan pada stasiun 1 ditemukan 150 spesies dengan $\mathrm{FBI}=6,58$, yang artinya termasuk kategori kualitas air buruk, dengan tingkat pencemaran terpolusi sangat banyak, pada stasiun 2 ditemukan 279 spesies dengan $\mathrm{FBI}=6,49$, yang artinya termasuk kategori kualitas air sangat buruk, dengan tingkat pencemaran terpolusi sangat banyak, pada stasiun 3 ditemukan 342 spesies dengan FBI=6,64, yang artinya termasuk kategori kualitas air buruk, dengan tingkat pencemaran terpolusi sangat banyak dan pada stasiun 4 ditemukan 51 spesies dengan $\mathrm{FBI}=6,58$, yang artinya termasuk kategori kualitas air buruk, dengan tingkat pencemaran terpolusi sangat banyak. Dari data sampel hewan makroinvertebrata yang ditemukan tersebut di atas terdiri dari 13 famili yang sebagian besar adalah makroinvertebrata yang tahan terhadap pencemaran.
\end{abstract}

Kata Kunci : Biomonitoring, bioindikator, makroinvertebrata

\section{PENDAHULUAN}

Kualitas lingkungan hidup yang semakin menurun dewasa ini mengancam kelangsungan perikehidupan manusia dan makhluk hidup lainnya sehingga perlu dilakukan perlindungan dan pengelolaan lingkungan hidup yang sungguh-sungguh dan konsisten oleh semua pemangku kepentingan.

Air sungai mempunyai peranan yang sangat strategis dalam kehidupan manusia dan makhluk hidup lainnya. Sungai memiliki sifat dinamis, maka dalam pemanfaatannya dapat berpotensi mengurangi nilai manfaat dari sungai itu sendiri dan dampak lainnya dapat membahayakan lingkungan secara luas. Lingkungan perairan sungai terdiri dari komponen abiotik dan biotik yang saling berinteraksi melalui arus energi dan daur hara. Bila interaksi keduanya terganggu maka akan terjadi perubahan yang menyebabkan 
ekosistem perairan itu menjadi tidak seimbang.

Obyek yang dikaji untuk dilakukan perlindungan dan pengelolaan kualitas lingkungan pada studi penelitian ini adalah Sungai Madiun. Sungai Madiun merupakan anak Sungai Bengawan Solo, Panjang total Sungai Madiun adalah $141 \mathrm{~km}$ dengan luas DAS sebesar $3.755 \mathrm{~km} 2$. Berdasarkan pengamatan, air limbah yang masuk ke dalam badan air Sungai Madiun berasal dari limbah rumah tangga dan air hujan yang membawa polutan dari daratan. Selain itu terdapat beberapa warga lokal yang tinggal di bantaran sungai melakukan mandi, membuang sampah, buang air kecil dan buang air besar di badan air Sungai Madiun. Selain itu pada beberapa titik masih terdapat masyarakat yang mandi dan buang air di badan air Sungai Madiun.

Kota Madiun secara fisik dibagi oleh Sungai Madiun yang membujur dari arah utara-selatan, menjadi dua bagian. Selain itu terdapat pula anak-anak Sungai Madiun yaitu Sungai Catur dan Sungai Sono yang merupakan saluran irigasi lahan pertanian di wilayah kota. Secara geografis Kota Madiun terletak pada $111^{\circ} \mathrm{BT}-112^{\circ} \mathrm{BT}$ dan $7^{\circ} \mathrm{LS}$ $8^{\circ}$ LS dan berbatasan langsung dengan Kabupaten Madiun di sebelah utara, sebelah selatan dengan Kecamatan Geger, sebelah timur dengan Kecamatan Wungu, dan sebelah barat dengan Kabupaten Magetan.

Kualitas air permukaan dapat ditentukan dengan menggunakan kombinasi parameter fisik-kimia dan biologis. Pengukuran menggunakan parameter biologis dapat digunakan untuk memantau secara kontinyu. Hal ini dikarenakan komunitas biota perairan menghabiskan seluruh hidupnya di lingkungan tersebut, sehingga bila terjadi pencemaran akan bersifat akumulasi atau penimbunan.
Biomonitoring adalah monitoring kualitas air secara biologi yang dilakukan dengan melihat keberadaan kelompok organisme petunjuk (indikator) yang hidup di dalam hidup di dalam air. Sedangkan makroinvertebrata adalah hewan tidak bertulang belakang yang hidup di dasar air laut atau sungai yang menempel pada air maupun lumpur. Keuntungan dari menggunakan makroinvertebrata sebagai bioindikator karena hidup melekat pada substrat dan motilitasnya rendah sehingga dia tidak mudah bergerak berpidah.

\section{METODE PENELITIAN}

Metode yang digunakan dalam penelitian ini adalah biomonitoring dengan bioindikator makroinvertebrata, teknik yang digunakan dalam mengambil sampel adalah dengan teknik purposive random sampling, sampling dilakukan di empat stasiun yaitu bagian hulu bagian tengah dan bagian hilir, pengambilan sampel dilakukan setiap 2 minggu sekali selama dua bulan.

Tahap terakhir dalam monitoring kualitas air adalah menganalisis data yang telah dikumpulkan untuk mendapatkan suatu nilai kuantitatif atau indeks. Indek penunjuk kualitas air dapat dihitung dengan beberapa cara, mulai dari cara yang sederhana hingga yang rumit. Analisis data yang dilakukan dalam biomonitoring kualitas air dengan metode Family Biotic Index (FBI). FBI adalah penghitungan indeks kualitas air yang dikembangkan oleh Hinsenhoff (1988) berdasarkan nilai toleransi (ketahanan terhadap perubahan lingkungan) dari tiap-tiap famili (Subekti Rahayu et al, 2009: 60). Menurut Prigi Arisandi (2012: C-301), menyebutkan bahwa perhitungan nilai indeks biotik makroinvertebrata bentik dengan Modified Family Biotic Index (FBI) telah 
banyak digunakan untuk mengindikasikan tingkat pencemaran organik di perairan, dimana tiap famili makroinvertebrata memiliki skor tertentu yang menunjukkan tingkat toleransi terhadap pencemaran organik. Oleh karena itu, perhitungan nilai indeks dengan Family Biotic Index (FBI) dapat dilakukan dalam penelitian untuk mendapatkan hasil sesuai dengan tujuan penelitian.

Menurut Prigi Arisandi (2012: C301) menyebutkan bahwa perhitungan nilai indeks biotik menggunakan rumus sebagai berikut:
$F B I=\sum_{i=1}^{i=n} \frac{x i \cdot t i}{N}$

Keterangan:

$\mathrm{FBI}=$ nilai indeks makroinvertebrata bentik

$\mathrm{i}=$ urutan kelompok familia yang menyusun komunitas makroinvertebrata

xi = jumlah individu kelompok famili ke-i

$\mathrm{ti}=$ tingkat toleransi kelompok famili ke-i

$\mathrm{N}=$ jumlah seluruh individu yang menyusun komunitas makroinvertebrata.

Interpretasi nilai biotik indeks untuk menentukan kualitas air dilakukan dengan mengikuti ketentuan yang sudah ada.

Tabel 4.1 Klasifikasi kualitas air berdasarkan Famili Biotik Indeks

\begin{tabular}{lll}
\hline $\begin{array}{c}\text { FAMILI BIOTIK } \\
\text { INDEKS }\end{array}$ & \multicolumn{1}{c}{$\begin{array}{c}\text { KUALITAS } \\
\text { AIR }\end{array}$} & \multicolumn{1}{c}{ TINGKAT PENCEMARAN } \\
\hline \hline $0,00-3,75$ & Sangat baik & Tidak terpolusi bahan organik \\
$3,76-4,25$ & Baik sekali & Sedikit terpolusi bahan organik \\
$4,26-5,00$ & Baik & Terpolusi beberapa bahan organik \\
$5,01-5,75$ & Cukup & Terpolusi agak banyak \\
$5,76-6,50$ & Agak buruk & Terpolusi banyak \\
$6,51-7,25$ & Buruk & Terpolusi sangat banyak \\
$7,26-10,00$ & Buruk sekali & Terpolusi berat bahan organik \\
& & \\
\hline
\end{tabular}

Sumber: Hilsenhoff (1988)

\section{HASIL PENELITIAN}

Dari hasil pengamatan yang telah sampel diperoleh data sebagai berikut : dilakukan dari empat stasiun pengambilan

Tabel 1. Hasil Pengamatan Fisik

\begin{tabular}{lcccc}
\hline \multicolumn{1}{c}{ Parameter } & Stasiun I & Stasiun II & Stasiun III & Stasiun IV \\
\hline Kecepatan aliran & $0,025 \mathrm{~m} / \mathrm{s}$ & $0,033 \mathrm{~m} / \mathrm{s}$ & $0,1 \mathrm{~m} / \mathrm{s}$ & $0,066 \mathrm{~m} / \mathrm{s}$ \\
\hline Kekeruhan & $20,5 \mathrm{~cm}$ & $25 \mathrm{~cm}$ & $27,5 \mathrm{~cm}$ & $35 \mathrm{~cm}$ \\
\hline Suhu & $25^{\circ} \mathrm{C}$ & $26^{\circ} \mathrm{C}$ & $25^{\circ} \mathrm{C}$ & $25^{\circ} \mathrm{C}$ \\
\hline $\mathrm{pH}$ & 7 & 7 & 7 & 7 \\
\hline
\end{tabular}


Tabel 2. Hasil Pengamatan Makroinvertebrata pada Stasiun I Berdasarkan Family Biotic Indeks (FBI)

\begin{tabular}{clccc}
\hline NO. & \multicolumn{1}{c}{ FAMILI } & $\begin{array}{c}\text { JUMLAH } \\
(\mathbf{X i})\end{array}$ & $\begin{array}{c}\text { TOLERANSI } \\
(\mathbf{t i})\end{array}$ & $\mathbf{X} \mathbf{i}^{*} \mathbf{t i}$ \\
\hline 1 & Caneidae & 2 & 7 & 14 \\
\hline 2 & Ephemerilidae & 2 & 1 & 2 \\
\hline 3 & Gomphidae & 4 & 3 & 12 \\
\hline 4 & Perlidae & 3 & 1 & 3 \\
\hline 5 & Ancylidae & 5 & 6 & 30 \\
\hline 6 & Thiaridae & 108 & 7 & 756 \\
\hline 7 & Bithyniidae & 3 & 8 & 24 \\
\hline 8 & Viviparidae & 5 & 6 & 30 \\
\hline 9 & Sphaeriidae & 12 & 6 & 72 \\
\hline 10 & Parathelphussidae & 6 & 6 & 36 \\
\hline & Jumlah & $\mathbf{1 5 0}$ & & $\mathbf{9 7 9}$ \\
\hline
\end{tabular}

Berdasarkan data tabel di atas nilai perhitungan Family Biotic Indeks (FBI) pada stasiun I adalah sebagai berikut :

$$
F B I=\frac{X i \times t i}{n}=\frac{979}{150}=6,58
$$

Jadi, hasil perhitungan FBI untuk stasiun I termasuk dalam kategori kualitas air buruk, dengan tingkat pencemaran terpolusi sangat banyak.

Tabel 3. Hasil Pengamatan Makroinvertebrata pada Stasiun II Berdasarkan Family Biotic Indeks (FBI)

\begin{tabular}{clccc}
\hline NO. & \multicolumn{1}{c}{ FAMILI } & $\begin{array}{c}\text { JUMLAH } \\
(\mathbf{X i})\end{array}$ & $\begin{array}{c}\text { TOLERANSI } \\
(\mathbf{t i})\end{array}$ & $\mathbf{X} \mathbf{X}^{*} \mathbf{*} \mathbf{i}$ \\
\hline 1 & Ephemerilidae & 1 & 1 & 1 \\
\hline 2 & Gomphidae & 3 & 3 & 9 \\
\hline 3 & Perlidae & 4 & 1 & 4 \\
\hline 4 & Ancylidae & 78 & 6 & 468 \\
\hline 5 & Thiaridae & 163 & 7 & 1141 \\
\hline 6 & Bithyniidae & 5 & 8 & 40 \\
\hline 7 & Viviparidae & 2 & 6 & 12 \\
\hline 8 & Sphaeriidae & 19 & 6 & 114 \\
\hline 9 & Parathelphussidae & 4 & 6 & 24 \\
\hline & Jumlah & $\mathbf{2 7 9}$ & & $\mathbf{1 8 1 3}$ \\
\hline
\end{tabular}

Berdasarkan data tabel di atas nilai perhitungan Family Biotic Indeks (FBI) pada stasiun I adalah sebagai berikut :

$$
F B I=\frac{X i \times t i}{n}=\frac{1813}{279}=6,49
$$

Jadi, hasil perhitungan FBI untuk stasiun II termasuk dalam kategori kualitas air buruk, dengan tingkat pencemaran terpolusi sangat banyak. 
Tabel 4. Pengamatan Makroinvertebrata pada Stasiun III Berdasarkan Family Biotic Indeks (FBI)

\begin{tabular}{clccc}
\hline NO. & FAMILI & $\begin{array}{c}\text { JUMLAH } \\
(\mathbf{X i})\end{array}$ & $\begin{array}{c}\text { TOLERANSI } \\
(\mathbf{t i})\end{array}$ & $\mathbf{X i * t i}$ \\
\hline 1 & Caneidae & 2 & 7 & 14 \\
\hline 2 & Ephemerilidae & 3 & 1 & 3 \\
\hline 3 & Gomphidae & 7 & 3 & 21 \\
\hline 4 & Perlidae & 2 & 1 & 2 \\
\hline 5 & Ancylidae & 42 & 6 & 1820 \\
\hline 6 & Thiaridae & 260 & 7 & 24 \\
\hline 7 & Bithyniidae & 3 & 8 & 18 \\
\hline 8 & Viviparidae & 3 & 6 & 32 \\
\hline 9 & Sphaeriidae & 12 & 6 & 5 \\
\hline 10 & Cordulegastridae & 1 & 3 & 36 \\
\hline 11 & Chlorocyphidae & 1 & 5 & $\mathbf{2 2 7 0}$ \\
\hline 12 & Parathelphussidae & 6 & 6 & \\
\hline & Jumlah & $\mathbf{3 4 2}$ & & \\
\hline
\end{tabular}

Berdasarkan data tabel di atas nilai

Jadi, hasil perhitungan FBI untuk stasiun perhitungan Family Biotic Indeks (FBI) pada stasiun I adalah sebagai berikut :

$$
F B I=\frac{X i \times t i}{n}=\frac{2270}{342}=6,64
$$
II termasuk dalam kategori kualitas air buruk, dengan tingkat pencemaran terpolusi sangat banyak

Tabel 5 Pengamatan Makroinvertebrata pada Stasiun IV Berdasarkan Family Biotic Indeks (FBI)

\begin{tabular}{clccc}
\hline NO. & FAMILI & $\begin{array}{c}\text { JUMLAH } \\
(\mathbf{X i})\end{array}$ & $\begin{array}{c}\text { TOLERANSI } \\
(\mathbf{t i})\end{array}$ & Xi*ti \\
\hline 1 & Gomphidae & 2 & 3 & 6 \\
\hline 2 & Ancylidae & 6 & 6 & 36 \\
\hline 3 & Thiaridae & 32 & 7 & 224 \\
\hline 4 & Bithyniidae & 2 & 8 & 16 \\
\hline 5 & Viviparidae & 3 & 6 & 24 \\
\hline 6 & Sphaeriidae & 4 & 6 & 12 \\
\hline 7 & Parathelphussidae & 2 & 6 & $\mathbf{3 3 6}$ \\
\hline & Jumlah & $\mathbf{5 1}$ & & \\
\hline
\end{tabular}

Berdasarkan data tabel di atas nilai perhitungan Family Biotic Indeks (FBI) pada stasiun I adalah sebagai berikut :

$$
F B I=\frac{X i \times t i}{n}=\frac{336}{51}=6,58
$$

Jadi, hasil perhitungan FBI untuk stasiun II termasuk dalam kategori kualitas air buruk, dengan tingkat pencemaran terpolusi sangat banyak. 


\section{PEMBAHASAN}

Dari penelitian berdasarkan parameter kimia yaitu $\mathrm{pH}$, di stasiun I, II, III dan IV masih berada di kisaran angka 7. Menurut Permenkes RI Nomor 416/MENKES/PER/IX/1990, pH 6,5-9,0 masih memenuhi standart kualitas air bersih. Pada stasiun I, II, III dan IV masih ditemui biota-biota air yang mampu bertahan hidup, namun menunjukkan jumlah dan jenis biota yang berbeda. Menurut Wisnu Arya Wardhana (2004: 75) yang menyatakan bahwa Air normal yang memenuhi syarat untuk suatu kehidupan mempunyai $\mathrm{pH}$ berkisar 6,5-7,5. Air limbah dan bahan buangan dari kegiatan industri yang dibuang ke sungai akan mengubah $\mathrm{pH}$ air yang pada akhirnya dapat mengganggu kehidupan organisme di dalam air.

Parameter pendukung selain parameter kimia adalah parameter fisik meliputi suhu, kecepatan aliran, dan kekeruhan. Berdasarkan hasil pengamatan di lapangan, suhu di stasiun I $25^{\circ} \mathrm{C}$, stasiun II $26^{\circ} \mathrm{C}$, stasiun III $25^{\circ} \mathrm{C}$ dan staisun IV $25^{\circ} \mathrm{C}$. Dari hasil penukuran tersebut, suhu masih memenuhi standart kualitas air bersih menurut Permenkes RI Nomor 416/MENKES/PER/IX/1990 yaitu berkisar antara $20^{\circ}-26^{\circ} \mathrm{C}$. Suhu tertinggi berada di stasiun II. Suhu berhubungan erat dengan kadar DO (Dissolved Oxygen) dalam air. Hal ini didukung oleh pernyataan yang menyebutkan bahwa hubungan antara suhu air dan oksigen biasanya berkorelasi negatif, yaitu kenaikan suhu di dalam air akan menurunkan tingkat solubilitas oksigen dan, dengan demikian, menurunkan kemampuan organisme akuatis dalam memanfaatkan oksigen yang tersedia untuk berlangsungnya proses-proses biologi di dalam air (Chay Asdak, 2010: 507).

Kecepatan aliran masing-masing stasiun berbeda-beda. Stasiun I memiliki kecepatan aliran $0,025 \mathrm{~m} / \mathrm{s}$, stasiun II memiliki kecepatan aliran $0,033 \mathrm{~m} / \mathrm{s}$, stasiun III memiliki kecepatan aliran $0,1 \mathrm{~m} / \mathrm{s}$ dan stasiun IV memiliki kecepatan aliran $0,066 \mathrm{~m} / \mathrm{s}$. Stasiun III memiliki kecepatan aliran paling tinggi karena struktur sedimen sungai yang cenderung dangkal, bebatuan dengan dasar pasir dan kerikil. Pada stasiun I karakter sungainya datar, berlumpur campur pasir dengan kedalaman lebih dalam dibandingkan dengan stasiun lainnya, sehingga mempunyai kecepatan aliran yang relatif lebih rendah dengan stasiun lainnya.

Parameter fisik terakhir yaitu kekeruhan. Kekeruhan stasiun I paling tinggi yaitu $20,5 \mathrm{~cm}$, stasiun II $25 \mathrm{~cm}$, stasiun III $27,5 \mathrm{~cm}$ dan stasiun IV $35 \mathrm{~cm}$ Kekeruhan pada stasiun I paling tinggi karena pada stasiun tersebut sungainya berlumpur.

Biomonitoring dilakukan dengan biondikator sebagai parameter utama dengan didukung parameter fisik dan kimia. Metode Family Biotic Index (FBI) merupakan metode perhitungan tingkat pencemaran suatu perairan dengan menggunakan indikator berupa keberadaan makroinvertebrata (invertebrata berukuran besar). Total makroinvertebrata yang ditemuan di aliran Sungai Madiun sebanyak 12 Famili, yaitu, Caneidae, Ephemerilidae, Gomphidae, Perlidae, Ancylidae, Thiaridae, Bithyniidae, Viviparidae, Sphaeriidae, Parathelphussidae, Cordulegastridae dan Chlorocyphidae. Famili makroinvertebrata paling banyak secara berturut-turut mulai dari stasiun III, I, II dan IV.

Berdasarkan hasil perhitungan FBI, stasiun I dengan nilai 6,58, yang berarti termasuk kategori kualitas air buruk, dengan tingkat pencemaran terpolusi sangat banyak. Makroinvertebrata dari famili Thiaridae dan Sphaeriidae ditemukan dengan jumlah yang 
paling banyak dibandingkan famili lain yang ditemukan di stasiun I, karena hewan famili ini memiliki nilai toleransi 7 artinya sangat tahan terhadap pencemaran, hal ini didukung dengan hasil penelitian yang dilakukan Stevi Mardiani M. M (2012) yang menyatakan bahwa famili Thiaridae merupakan kelompok makroinvertebrata yang tahan bahan pencemar. Pada stasiun II memiliki nilai FBI sebesar 6,49, berarti termasuk dalam kategori agak buruk, dengan tingkat pencemaran terpolusi banyak. Makroinvertebrata dari famili Thiaridae dan Ancylidae memiliki jumlah yang banyak pada stasiun ini dibandingkan famili lainnya. Stasiun III memiliki nilai FBI sebesar 6,64, berarti termasuk dalam kategori buruk, dengan tingkat pencemaran terpolusi sangat banyak. Miskipun Pada stasiun ini ditemukan jumlah species dan jumlah famili paling banyak yaitu 342 species dan 12 famili, namun memiliki indek FBI paling tinggi. Makroinvertebrata dari famili Thiaridae dan Ancylidae memiliki jumlah yang paling banyak dibandingkan 12 famili lainnya. Pada stasiun IV memiliki nilai FBI sebesar 6,58 yang berarti memiliki kategori yang sama dengan stasiun I, II dan III yaitu kategori buruk, dengan tingkat pencemaran terpolusi sangat banyak. Pada stasiun ini ditemukan paling sedikit species dan jumlah famili, yaitu 51 species dan 7 famili, dengan species paling banyak ditemukan pada famili Thiaridae selanjutnya famili Ancylidae.

Berdasarkan hasil penelitian dengan bioindikator berupa makroinvertebrata, masing-masing stasiun memiliki jenis famili masing-masing yang toleran dengan kondisi perairan yang ada. Famili Thiaridae dari Ordo Gastropoda memiliki toleransi yang baik dengan kondisi perairan mulai dari yang tercemar ringan sampai berat. Namun untuk famili Ephemirilidae dan Perlidae sudah tidak ditemukan distasiun IV, karena hewan ini memiliki nilai toleransi 1 yang artinya tidak toleran atau sensitif terhadap perairan yang tercemar.

Famili Thiaridae ditemui di semua stasiun dan mendominasi, karena famili ini termasuk makroinvertebrata yang tahan terhadap pencemaran. Hal ini didukung dengan hasil penelitian yang dilakukan Rotua Lelawati S. et al (Tanpa Tahun) menyatakan bahwa makroinvertebrata yang lebih tahan terhadap pencemaran seperti Chironomidae merah (Diptera) dan satu kerang-kekerangan, yaitu Thiaridae (Mesogastropoda) muncul pada seluruh stasiun.

Metode FBI mampu menilai tingkat pencemaran Sungai Madiun yang dibagi menjadi empat stasiun penelitian. Berdasarkan nilai FBI tersebut nilai FBI tertinggi adalah pada stasiun I, karena pada stasiun ini air telah melalui perkotaan, dimana semua limbah, baik limbah pabrik, limbah rumah tangga, limbah pasar, dan limbah rumah sakit bermuara di stasiun ini. Menurut Stevi Mardiani M. M., (2012: 11) menyatakan bahwa apabila terdapat bahan pencemar dalam perairan, maka biota yang sangat peka akan hilang karena tidak mampu bertahan hidup. Sebaliknya biota yang sangat toleran, akan tetap dapat hidup pada kualitas air yang buruk. Setiap stasiun memiliki makroinvertebrata yang mendominasi keberadaannya, sehingga terlihat biota yang toleran terhadap kualitas air yang buruk atau tidak.

\section{SIMPULAN}

Berdasarkan hasil penelitian yang telah dilakukan, maka dapat disimpulkan bahwa makroinvertebrata dapat dijadikan bioindikator dalam melakukan biomonitoring Sungai Madiun. Metode Family Biotic Index 
(FBI) mampu menentukan kualitas air stasiun I, II, III dan IV. Makroinvertebrata yang ditemukan di aliran Sungai Madiun sebanyak 12 Famili, yaitu Caneidae, Ephemerilidae, Gomphidae, Perlidae, Ancylidae, Thiaridae, Bithyniidae, Viviparidae, Sphaeriidae, Parathelphus-sidae, Cordulegastridae dan Chlorocy-phidae. Famili makroinvertebrata paling banyak secara berturut-turut mulai dari stasiun III, I, II dan IV

Stasiun I memiliki nilai FBI sebesar 6,58 yang berarti termasuk dalam kategori buruk, dengan tingkat pencemaran terpolusi sangat banyak. Stasiun II memiliki nilai FBI sebesar 6,49 yang berarti termasuk dalam kategori agak buruk, dengan tingkat pencemaran terpolusi banyak. Stasiun III memiliki nilai 6,82 yang berarti termasuk dalam kategori buruk, dengan tingkat pencemaran terpolusi sangat banyak. Stasiun IV memiliki nilai 6,58 yang berarti termasuk dalam kategori buruk, dengan tingkat pencemaran terpolusi sangat banyak. Makroinvertebrata yang banyak ditemu-kan di seluruh stasiun adalah famili Thiaridae, sehingga dapat diketahui bahwa Famili Thiaridae mampu beradaptasi dengan kualitas air yang baik hingga sangat buruk.

\section{DAFTAR PUSTAKA}

Agoes Soegianto. 2005. Ilmu Lingkungan Sarana Menuju Masyarakat Berkelanjutan. Surabaya: Airlangga University Press.

Anang Prasetyo et al. 2004. SAINS 1 (Energi dan Perubahannya Bumi dan Alam Semesta). Jakarta: PT Grasindo.

Badan Lingkungan Hidup, Riset, dan Teknologi Informasi. 2010. Laporan Pemantauan Kualitas Air Sungai di
Provinsi Gorontalo. Gorontalo : BALIHRISTI

Chay Asdak. 2010. Hidrologi dan Pengelolaan Daerah Aliran Sungai. Yogyakarta: Gadjah Mada University Press.

Campbell, Neil A. dan Reece, Jane B. 2008. Biologi Edisi Kedelapan Jilid 1. Terjemahan oleh Damaring Tyas Wulandari. 2010. Jakarta: Erlangga.

2008. Biologi Edisi Kedelapan Jilid 2. Terjemahan oleh Damaring Tyas Wulandari. 2010. Jakarta: Erlangga.

Daud, Anwar. 2011. Analisis Kualitas Lingkungan. Yogyakarta: Ombak Effendi, Hefni. 2008. Telaah Kualitas Air. Yogyakarta: Kanisius

Direktorat Jenderal Pendidikan Tinggi Departemen Pendidikan Nasional. 2009. Pedoman Operasional Penilaian Angka Kredit Kenaikan Jabatan Fungsional Dosen Ke Lektor Kepala dan Guru Besar, (online), (http://www.dikti.go.id/files/atur/ Pedoman Nilai Lektor Kepala-Guru Besar.pdf. Diunduh 15 Maret 2014

Eleftherion, A. and Mclntyre, A. 2005. Methods for The Study Marine Benthos Third Edition. Department of Biologi, University of Crete, Greece and Hellenic Centre for Marine Research, Crete, Greece, Blackwell Science, Australia. Ghufran H. Kordi K dan Andi Baso Tancung. 2007. Pengelolaan Kualitas Air dalam Budidaya Perairan. Jakarta: PT Rineka Cipta.

Hamidi. 2004. Metode Penelitian Kualitatif. Malang: UMM Press 
Hilda Zulkifli dan Doni Setiawan. 2011. Struktur Komunitas Makrozoobentosdi Perairan Sungai Musi Kawasan Pulokerto sebagai Instrumen Biomonitoring. Jurnal Natur Indonesia (Online), (http://ejournal.unri.ac.id/index.php/ JN/article/view/202/196, Diunduh 12 Maret 2014).

H. J. Mukono. 2006. Prinsip Dasar kesehatan Lingkungan. Surabaya: Airlangga University Press.

Juli Soemirat Slamet. 2000. Kesehatan Lingkungan. Yogyakarta: Gadjah Mada University Press.

Kaligis, Samidjo Broto K., dan Mieke M.. 2005. Materi Pokok Pendidikan Lingkungan hidup. Jakarta: Universitas Terbuka.

Karden Manik, E. S. 2003. Pengelolaan Lingkungan Hidup. Jakarta: Djambatan.

Lintang Rina K., Mustofa N. S., dan Suryanti. 2012. Kondisi Perairan Berdasarkan Bioindikator Makrobentos Di Sungai Seketak Tembalang Kota Semarang. Jurnal Of Management Of Aquatic Resources (Online), Vol. I, No.1, (http://download.portalgaruda.org, Diunduh tanggal 16 Februari 2014)

Lintang Rina K., Mustofa N. S., dan Suryanti. 2012. Kondisi Perairan Berdasarkan Bioindikator Makrobentos Di Sungai Seketak Tembalang Kota Semarang. Jurnal Of Management Of Aquatic Resources (Online), Vol. I, No.1, (http://download.portalgaruda.org, Diunduh tanggal 16 Februari 2014)

Muhammad dan Adhi. 2004. Modul Ajar Pengelolaan Kualitas Air. Surabaya: Jurusan Teknik Lingkungan Fakultas Teknik Sipil dan Perencanaan Institut Teknologi sepuluh Nopember (ITS).
Nana Syaodih Sukmadinata. 2012. Metode Penelitian pendidikan. Bandung: PT

Odum, P.E. 1994. Dasar-Dasar Ekologi. Gadjah Mada University Press, Yogyakarta.

Otto Soemarwoto. 2001. Analisis Mengenai Dampak Lingkungan. Yogyakarta: Gadjah Mada University Press.

Peni Pujiastuti, Bagus Ismail, dan Pranoto. 2013. Kualitas dan beban Pencemaran Perairan Waduk Gajah Mungkur. Jurnal EKOSAINS (Online), Vol. V, No. 1, (http://ejournal.unri.ac.id/index.php/ JN/article/view/202, Diunduh 12 Maret 2014)

Peraturan Pemerintahan Republik Indonesia Nomor 82 Tahun 2001 tentang Pengelolaan Kualitas Air dan Pengendalian Pencemaran Air. 2002. Jakarta: Kementerian Lingkungan Hidup.

Philip Kristanto. 2002. Ekologi Industri. Yogyakarta: Andi

Pramitha, Soraya. 2010 . Analisis Kualitas Air Sungai Aloo, Sidoarjo Berdasarkan Keanekaragaman Dan Komposisi Fitoplankton. Skripsi. Surabaya : Institut Teknologi Sepuluh November. (http://Digilib.its.ac.id, diakses 12 Desember 2013).

Prigi Arisandi. 2012. Studi Kualitas Air Sungai Bone dengan Metode Biomonitori (Online), Prosiding Seminar Nasional Kimia Unesa 2012, (http://fmipa.unesa.ac.id/kimia/wpcontent/uploads/2013/11/298-309Prigi-Arisandi.pdf, Diunduh 31 Januari 2014). 
Prima Firstyananda. Tanpa Tahun. Komposisi dan Keanekaragaman Makrozoobentos Di Tiga Lokasi Aliran Sungai Sumber Kuluhan Jabung, Kabupaten Magetan, (online), (http://biologi.fst.unair.ac.id/wpcontent/uploads/2012/04/jurnalKeanekaragaman-Makrozooentosdi-tiga-lokasi-aliran-sungai-sumberKuluhan-Jabung-Kab.-Mage.pdf, Diunduh 12 Maret 2014)

Rahayu, Rudy, Meine, Indra, dan Bruno. 2009. Monitoring Air di Daerah Aliran Sungai. Bogor : World Agroforestry Centre

Ratna Siahaan, Andry Indrawan, Dedi Soedharma, dan Lilik B. Prasetyo. 2011. Kualitas Air Sungai Cisade, Jawa Barat-Banten. Jurnal Ilmiah Sains, (Online), Vol. 11, No. 2, (http://ejournal.unsrat.ac.id, Diunduh 12 Maret 2014).

Ricki M. Mulia. 2005. Kesehatan Lingkungan. Yogyakarta: Graha Ilmu.

Rifgah Marmita, Ratna Siahaan, Roni Koneri, Marnix L. Langoy. 2013. Makrozoobentos sebagai Indikator Biologi dalam Menentukan Kualitas air Sungai Ranoyapo, Minahasa Selatan, Sulawesi Utara, (online), (http://ejournal.unsrat.ac.id/index.ph p/JIS/article/view/2033, Diunduh 31 Januari 2014).

Rotua Lelawaty S., Amran Achmad, dan Inayah Yasir. (Tanpa Tahun). Kualitas Air Sungai Bone (Gorontalo) Berdasarkan Bioindikator Makroinvertebrata, (online), (http://pasca.unhas.ac.id/jurnal/files/ d78f702d6fc5cbed32df6dc08465387 7.pdf, Diunduh 12 Maret 2014).
Sabaruddin Wagiman Tjokrokusumo. 2006. Bentik Makroinvertebrata sebagai Bioindikator Polusi Lahan Perairan. Jurnal Hidrosfir (Online), Vol. 1, No. 1 , (http://ejurnal.bppt.go.id/index.php/J HI/article/view/79/185, Diunduh 31 Januari 2014).

Stevi Mardiani M. Maruru. 2012. Studi Kualitas Air Sungai Bone Dengan Metode Biomonitoring. Skripsi. Jurusan Kesehatan Masyarakat, Fakultas Ilmu-Ilmu Kesehatan dan Keolahragaan, Universitas Negeri Gorontalo.

Subekti Rahayu, Rudi Harta Widodo, Meine van Noordwijk, Indra Suryadi, dan Bruno Verbist. 2009. Monitoring Air Di Daerah Aliran Sungai. Bogor: World Agroforestry Centre.

Suripin. 2004. Pelestarian Sumber Daya Tanah dan Air. Yogyakarta: Andi.

Sumadi Suryabrata. 2011. Metodologi Penelitian. Jakarta: PT Rajagrafindo Persada.

Tresna Sastrawijaya. 2009. Pencemaran Lingkungan. Jakarta: PT Rineka Cipta.

Wisnu Arya Wardhana. 2004. Dampak Pencemaran Lingkungan. Yogyakarta: Andi Offset.

Zoer'aini Djamal Irwan. 2003. Prinsip-Prinsip Ekologi dan Organisasi Ekosistem Komunitas dan Lingkungan. Jakarta: PT Bumi Aksara.

Zoer'aini Djamal Irwan. 2003. Prinsip-Prinsip Ekologi dan Organisasi Ekosistem Komunitas dan Lingkungan. Jakarta: PT Bumi Aksara. 